\title{
Mary Warnock \\ (1924-2019)
}

Philosopher who crafted governance for embryo research.

$\mathrm{P}$ hilosopher Mary Warnock was one of the architects of the age of biology. She is responsible for the United Kingdom's strictly regulated but highly permissive climate for animal experimentation, embryo research and assisted reproduction, which has enjoyed widespread support for more than 30 years. This system has enabled techniques such as in vitro fertilization (IVF), cloning, the derivation of stem cells from human embryos, and human-embryo research to receive legislative approval, bipartisan government backing and public endorsement to an extent that is unique to the United Kingdom.

Warnock developed her distinctive approach to the legislation of controversial topics by drawing on her training as a scholar of ethics and morality, and her experience of chairing high-level public, professional and government committees. Her two dozen books and government reports, as well as hundreds of articles and book chapters, also mined her experience as an educational innovator and mother of five. It is a legacy worth reflecting on, as we attempt to establish viable global governance of genome editing.

Helen Mary Wilson was born in Winchester, UK, in 1924. In 1942, she began studying for her bachelor's and doctoral degrees at Lady Margaret Hall at the University of Oxford, UK, and in 1949 married her colleague Geoffrey Warnock. The academic power couple presided over a renaissance in British philosophy, and headed a pair of Oxbridge colleges in the 1980s - Mary as mistress of Girton College at the University of Cambridge, and Geoffrey as principal of Hertford College before he became Oxford's 265 th vice-chancellor.

Warnock's initial philosophical contributions in the 1960s centred on the work of Jean-Paul Sartre, who was then little known in Anglophone philosophy (the first monograph in English on his work was written by Warnock's Oxford colleague and friend Iris Murdoch, in 1953). Warnock argued (as did philosopher Simone de Beauvoir) that Sartre's view of freedom as the defining human condition negated the vastly different circumstances of individual lives and the social bonds between them.

This early commitment to what Warnock would later call "the moral idea of society" was central to her definition of successful policy, and to her ability to deliver effective legislation related to questions on which people had strong feelings. Building on

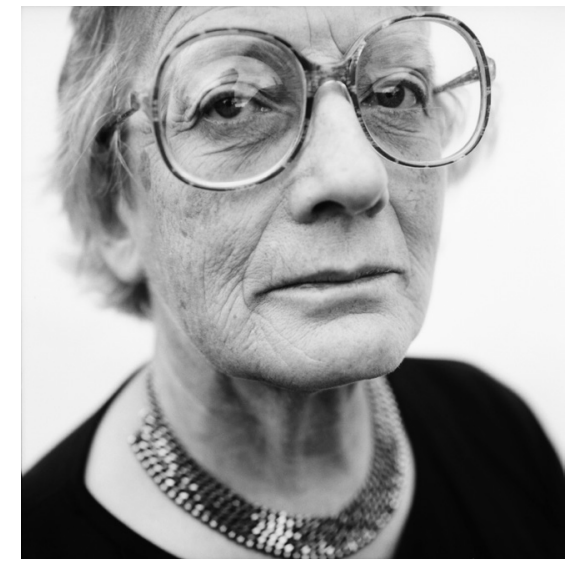

her distinguished academic credentials, Warnock spent the second half of her life leading a series of pivotal public enquiries, commissions and committees.

In 1974, she was appointed to chair the Committee of Inquiry into Special Education, resulting in the publication of the first 'Warnock Report' in 1978, with its signature combination of progressive, principled, pragmatic and plainly worded recommendations. These included the proposal that children with special needs be integrated into mainstream schools, and educated alongside their peers, for the benefit of both.

1978 was also the year Louise Brown, the world's first 'test-tube baby', was born in Oldham, UK, to the surprise of some and the consternation of many who viewed humanembryo research with suspicion. The early 1980s were a period of political backlash against the social reforms of the 1960s and 1970s, and many social conservatives considered the prospect of regulating humanembryo experimentation to be a golden opportunity to repeal the law permitting abortion, and to return to 'traditional family values.

In response to the public and parliamentary demand for legislation to govern new forms of assisted conception, a Committee of Inquiry into Human Fertilisation and Embryology was established, with Warnock as its chair, in 1982. From the outset, it was clear that the issue of embryo research would prove to be one of the most difficult on which to reach a consensus. Furthermore, Warnock realized that philosophical, religious and bioethical arguments about 'the moral status of the human embryo' were likely to impede rather than ease the process of reaching agreement. Deftly side-stepping this divisive argument, on which she felt no agreement was ever likely, Warnock offered an alternative form of moral reasoning that provided enough common ground for agreement to be reached.

What was essential, she argued, was for some regulation of embryo experimentation to be established, because the alternative was no regulation - "and this nobody wants" (see go.nature.com/2ucqmzz). Moreover, Warnock urged, there had to be limits; and if these could not be defined in a manner that was 'right' for everyone, they at least had to be 'all right' for enough people to be passed into law. She proposed a formula: in exchange for allowing some forms of assisted conception and embryo research to continue, these procedures would be subject to strict limits, and to the highest levels of scrutiny.

A pragmatist, she translated the moral idea of society into a sociological principle of reciprocity that could underpin successful policy. In return for science's benefits, accountable and transparent governance has to be persuasively established and maintained. She also argued, and proved through many successful interventions, that a single rationale for good science policy is not enough. Robust governance of controversial translational research must follow multiple strands of reasoning, from science, ethics, social norms, law and common sense.

For 35 years, Warnock's framework for regulating human-embryo research and assisted reproduction - and its landmark licensing system, now the Human Fertilisation and Embryology Authority - have been admired worldwide. Yet no other country has replicated Britain's tightly regulated and legally binding, but popular and open-minded, system of biogovernance. This is unfortunate in the contexts of both a burgeoning privatesector fertility industry and the merging of IVF with CRISPR gene editing into a technological platform with unprecedented scope for altering human futures.

Mary's deeply compassionate yet hardnosed approach to delivering social consensus from the busy mangle of innovation offers increasingly important lessons for us all as the age of biology continues to unfold..

Sarah Franklin chairs sociology and directs the Reproductive Sociology Research Group (ReproSoc) at the University of Cambridge, UK. The 2008 interview she and Martin H. Johnson conducted with Mary Warnock is part of the British Library Sound Archive. e-mail:sbf25@cam.ac.uk 